\title{
Last-Millennium Settlement on Yadua Island, Fiji: Insights into Conflict and Climate Change
}

\author{
$\mathbf{\Delta} \cdot \mathbf{\Delta} \cdot \mathbf{\Lambda}$ \\ Piérick C. M. Martin, Patrick D. Nunn, Niko Tokainavatu, \\ Frank Thomas, Javier LeOn, and Neil Tindale
}

\begin{abstract}
A 50-70 cm sea-level fall around A.D. 1300 may have led to a prolonged food crisis which caused conflict among coastal dwellers on high Pacific islands. The conflict may have necessitated abandoning difficult to defend coastal settlements and establishing ones in fortifiable locations inland. To test this idea, abandoned hillforts (koronivalu) on $20 \mathrm{~km}^{2}$ Yadua Island were studied. Yadua Island is $20 \mathrm{~km}$ off the western extremity of Vanua Levu Island, the second largest island in the Fiji archipelago, where many such hillforts once existed. Human-made structures (stone walls), artifacts (potsherds and lithics), and accumulations of edible seafood waste (shellfish middens), all implying sustained occupation, were identified at four sites in upland Yadua, including two hillforts (Koromakawa and Uluinakoro) and two lookout posts (Nacelau and Uluikota). Radiometric ages suggest the two hillforts were occupied during the seventeenth century or perhaps established earlier, making them coeval with hillforts elsewhere in Fiji and other tropical Pacific Island groups. Information about Pacific Islands settlement throughout the last millennium can still be obtained from islands like Yadua through fieldwork and the collection of oral traditions. Oral traditions and human-made structures are likely to disappear within a few decades, owing to the increasing reach of globalization and ongoing physical degradation respectively; research of the kind described in this article is thus a priority. KEYWORDS: climate change, conflict, settlement pattern, fortification, oral tradition, Pacific Islands.
\end{abstract}

\section{INTRODUCTION}

INTEREST IN THE WAY THAT CLIMATE AND SEA-LEVEL CHANGES have impacted the environment and human societies in different parts of the world has been growing steadily over the last two decades. It has become clear from a number of case studies that rapid climate change has often dislodged particular societies from their evolutionary trajectories (Büntgen et al. 2016; Cannon 2015; Chew and Sarabia 2016; Liu and Feng 2012). Given their inherent geographical vulnerability, as apparent today as in the pre-globalization era, oceanic islands have been a subject of considerable interest

Piérick C. M. Martin is a Master's degree student at the University of the Sunshine Coast, Australia. Patrick D. Nunn is a Professor at the University of the Sunshine Coast. Niko Tokainavatu is an Archaeologist at the Fiji Museum, Fiji. Frank Thomas is a Senior Lecturer at the University of the South Pacific, Fiji. Javier Leon is a Senior Lecturer at the University of the Sunshine Coast. Neil Tindale is an Associate Professor at the University of the Sunshine Coast. 
to archaeologists and others interested in the historical interactions between climate change and humans (Kirch et al. 2004; Nunn 2007b; Rick et al. 2013).

Oceanic-island societies - today and in the past-experience similar pressures as continental societies, but their vulnerability is exacerbated by comparatively limited physical space, high insularity ratios, small populations, small watersheds, limited terrestrial biodiversity, narrow range of land resources, and high exposure to natural hazards (Di Piazza and Pearthree 2001; Fitzpatrick and Anderson 2008; Weisler 1996). Some small insular communities were able to harness locally abundant resources in a sustainable way, most notably nearshore marine resources (Fitzpatrick et al. 2016; Giovas 2016; Harris and Weisler 2017; Keegan et al. 2008).

Like today, climate and sea level changes were major stressors of most oceanic island societies in the past. It has been suggested, for instance, that sea levels fell below a critical threshold (ca. $2570 \mathrm{cal}$. B.P.), causing the rapid collapse of the useful bioproductivity of nearshore marine ecosystems and reducing access to freshwater lenses perched just above sea level. This compelled many coastal marine foraging communities in the Western Pacific islands to re-locate their settlements and reconfigure their subsistence economies to the point where they became dependent on horticulture or agriculture (Dickinson and Athens 2007; Nunn and Carson 2015b).

A similar situation has been suggested as having occurred during the so-called "A.D. 1300 Event," a century long period of sea-level fall of perhaps $50-70 \mathrm{~cm}$ which occurred ca. A.D. 1250-1350 across most of the tropical Pacific. Bookended by the Medieval Warm Period (A.D. 750-1250) and the Little Ice Age (A.D. 1350-1800), the A.D. 1300 Event was characterized by rapid cooling, likely triggered by a decrease in solar irradiance, decrease in atmospheric $\mathrm{CO}_{2}$, or an increase in El Niño frequency (Kouwenberg et al. 2005; Nunn 2007a; Perry and Hsu 2000; Weber et al. 2004). On many Pacific Islands, the cooler temperatures, changed climatic conditions, and sealevel fall resulted in an estimated 80 percent decrease in coastal food production within a hundred years, leading to a prolonged food crisis that in turn caused conflict (Nunn 2007b). On some high tropical Pacific Islands, it has been proposed that conflict necessitated the abandonment of indefensible coastal settlements and establishment of new ones in fortifiable locations, typically on hilltops or in caves. Good examples come from various Fiji Islands (Kumar et al. 2006; Robb and Nunn 2012), Rapa Island in French Polynesia (Anderson et al. 2012), and Timor Leste (O'Connor et al. 2012). Elsewhere in the Pacific Islands region, the process-response system outlined above appears less clear (Fitzpatrick 2010, 2011; Nunn and Hunter-Anderson 2011). However, many studies have concluded that the Medieval Warm Period (a.k.a., Little Climatic Optimum) was a time of plenty that allowed population growth and increasing societal complexity; this period contrasts to the Little Ice Age, a time of less resources when climate-driven food crises became more common and widespread (Field 2008; Lape and Chin-Yung 2008; Nunn et al. 2007).

The present study focuses on Yadua, a small remote island in northern Fiji that was the subject of intensive fieldwork involving the mapping and sampling of former hillforts (koronivalu) and collection of oral traditions. The research sought to test whether or not hillforts on Yadua had been established in response to climate-forced settlement change during the last millennium. This research illustrates the value of using multiple lines of research (i.e., geoarchaeological, anthropological, oral historical) and the intrinsic interest in examining comparatively remote locations within the tropical Pacific. 


\section{AIMS AND CONTEXT}

The goals of this research were to identify, describe, and interpret hillforts on Yadua Island and evaluate whether their establishment could be explained by the effects of the A.D. 1300 Event. Following correspondence with other researchers (Wendy Taylor and Roselyn Kumar) active in this part of Fiji, the island of Yadua was chosen as a study site because it was likely to contain historic hillforts.

Yadua Island was occupied by some of the earliest Fijians (i.e., the Lapita people) around $2600 \mathrm{cal}$. B.P., likely because of the availability of fresh water on the island and its proximity to a broad fringing-barrier reef complex (Nunn et al. 2005). As elsewhere in Fiji, the last-millennium history of Yadua is likely to have included the construction, occupation, and eventually the abandonment of hillforts. Studies of these along the north coast of Viti Levu Island, some $80 \mathrm{~km}$ from Yadua, show that a preliminary phase of hillfort construction likely occurred here between A.D. 1200-1400 with a more concentrated phase around A.D. 1300-1500 (Nunn 2012). A similar conclusion to that was reached for hillforts in the Sigatoka Valley on the same island (Field 2004; Kumar et al. 2006). Hillforts were also described in nineteenth century accounts of the landscape of western Vanua Levu, which was the target of early sandalwood and bêchede-mer (sea cucumber) trading in Fiji (Guppy 1903; Wilkes 1845). Recent research described the Koivuanabuli hillfort on Mali Island, off the central north coast of Vanua Levu (Burley et al. 2015); other hillforts have been noted on the adjacent mainland (Palmer 1966).

Arguing that the hitherto unexplained transformation of human settlement on tropical Pacific Islands from coastal/peaceable to inland/warlike was approximately contemporaneous, it has been proposed that this transformation was driven by climate change (Nunn 2007b). Specifically, global cooling between the Medieval Warm Period and the Little Ice Age around A.D. 1300 led to a fall in the sea level by perhaps as much as $70 \mathrm{~cm}$, which devastated food production along island coasts (Nunn and Carson 2015a). The enduring nature of this impact inevitably led to conflicts between clans in a quest to obtain food. This in turn forced people out of their customary coastal settlements and into more sheltered and defensible contexts, many of which (like mountaintops and deep caves) lent themselves to fortification. For small islands such as Yadua, the main threats likely came from other islands, including presumably Vanua Levu just $20 \mathrm{~km}$ east. The so-called A.D. 1300 Event model has been proposed as an explanation for the Pacific-wide outbreak of conflict (and attendant societal disruption). This conflict is commonly marked in high island groups by a shift from coastal to inland or upland settlement (Kennett et al. 2006; Nunn 2007b; Pearl 2004). Alternative cogent arguments invoke climate change, rather than sea-level change explicitly, as an explanation for the start of the hillfort period often observed in the Pacific region (Field and Lape 2010; Lape and Chin-Yung 2008).

\section{STUDY SITE AND METHODS}

The volcanic island of Yadua covers an area of about $20 \mathrm{~km}^{2}$ (Fig. 1). Its highest peak, Korobalavu, stands approximately $200 \mathrm{~m}$ above mean sea level (amsl). Today there is only one settlement (Denimanu) on Yadua, but formerly there were more, including coastal villages at Cukuvou and Vagairiki and number of inland settlements. The presence of these earlier settlements is often recalled through the use of the prefix or 


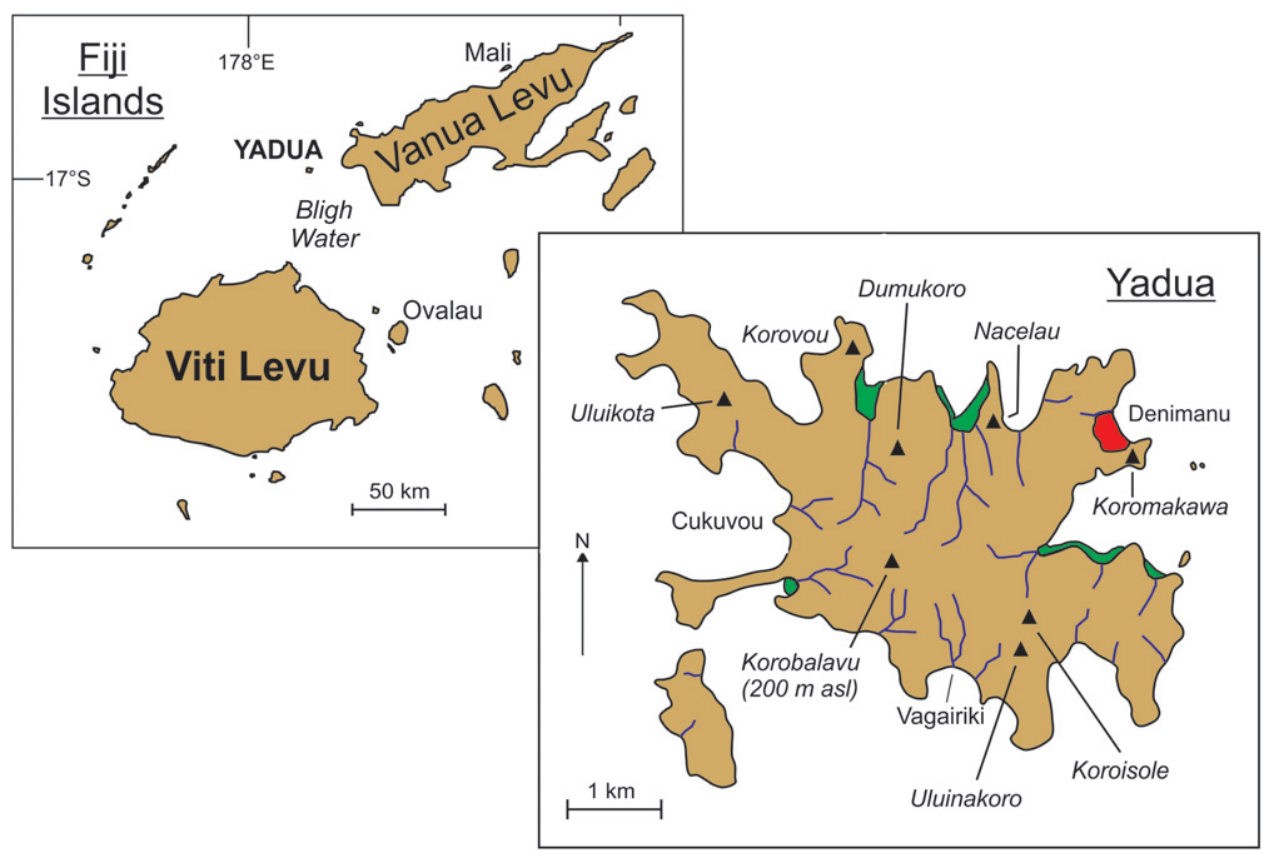

Fig. 1. Sketch maps: (top left) Location of Yadua Island relative to Fiji Islands (map created by Patrick Nunn); (lower right) Yadua Island, showing principal places mentioned in text (after Nunn et al. 2005).

suffix koro (meaning "human settlement" in the Fijian language) in place names; the names of hilltops on Yadua often include this affix.

Examination of place names on Yadua, especially those including "koro," helped identify potential hillforts on the island, but even more helpful were informants in Denimanu who knew of hilltop sites that had the remains of human-built structures (i.e., stone walls [bainivatu] and house platforms [yavu]) or stories that associated these places with former occupation. Thus, field survey was supplemented by formal recordings of oral traditions from Yadua Island resident elders about the island's hillforts (Ethics approval number: S/17/1082). Story telling sessions were usually fueled by kava (yaqona) consumption, which creates cultural contexts in rural Fiji settings suited to information exchange and discussion. Oral traditions are inevitably incomplete but were sufficient to point the researchers towards promising sites. On many hilltops, the remains of earthenware pots (kuro) and edible shellfish (qanivivili) were reported. With this information in hand, a systematic survey of eight potential upland sites on Yadua was undertaken using a hand-held GPS (Garmin GPSmap 62s) with a locational error of approximately $2-5 \mathrm{~m}$. Excavations were made at promising sites, with samples recovered for subsequent analysis and radiocarbon age determination. Two test pits were dug at Uluinakoro and one at Koromakawa. Each pit measured $1 \times 1 \mathrm{~m}$ and varied in depth depending on artifact productivity $(40 \mathrm{~cm}$, $30 \mathrm{~cm}$, and $170 \mathrm{~cm}$ respectively).

Potsherds recovered from different layers in the hillfort excavations were cleaned and photographed so that any decoration could be noted to help determine the approximate age of the occupation. The pottery pieces are stored at the Fiji Museum in 
Suva. Shell remains of edible shellfish, carried to the hillfort to be consumed there by its occupants, were also sampled to identify samples for radiocarbon age determination. Only filter-feeding bivalves such as Anadara and Gafrarium, which are best suited for radiocarbon dating (Nunn and Petchey 2013), were selected as samples; they were isolated and cleaned before being sent to the University of Waikato's Radiocarbon Dating Laboratory.

\section{RESULTS AND INTERPRETATION}

\section{Ridgetop Sites}

Human-made structures (mainly stone walls), implying sustained occupation, were identified at four sites in upland Yadua: Koromakawa, Nacelau, Uluikota, and Uluinakoro (Fig. 1). Detailed mapping of the Uluinakoro site shows it to be a typical ridgetop site similar in form to many others in Fiji (Palmer 1969), including the Vatutāqiri site on the Vatia Peninsula in northern Vanua Levu (Robb and Nunn $2014 b$ ) (Fig. 2). Approached by narrow, steep-sided ridges (tua), the summit of Uluinakoro is cut into three artificial terraces surmounted by two rock walls and a house foundation. These suggest that the highest part of the site $(>150 \mathrm{~m}$ amsl) was occupied by an elite group who were protected by at least one guardhouse. The terraces were likely cut by people for dwellings of non-elite groups or food gardens. The visible record of human occupation on the summit of Uluinakoro is incomplete; much of the area has been farmed and is covered by low grass that barely protects any underlying structures, resulting in their dismantling and dispersal.

The Nacelau site is interpreted as a subsidiary site, serving both as a first line of defense against people seeking to approach or attack higher sites such as Uluinakoro and as a lookout, especially at times when higher sites might have been shrouded in cloud (Fig. 3). In this, Nacelau is similar to the lower subsidiary defensive sites like Drautana that were built along ridgelines leading to Vatutāqiri (Robb and Nunn 2014b). The visible record of occupation at Nacelau is restricted, probably because the site's physical properties were not favorable for a large settlement, but the positioning of house platforms ( $y a v u$ ) supports the interpretation of the site as both a lookout and a defensive outpost. Two yavu were mapped on the ridge spur in a location where natural defensive attributes such as steep cliffs have been accentuated by the construction of stone walls, one of which was traced for $24 \mathrm{~m}$. Three rock piles $(3 \times 0.6 \mathrm{~m}$ each) were observed along the narrow promontory approximately $100 \mathrm{~m}$ apart. According to local informants, these rock piles may have served as warnings to approaching outsiders that the island was occupied; the rocks themselves could also have been used as weapons against potential enemies.

The site known as Koromakawa ("Old Village") is a sizeable settlement located on a $40 \mathrm{~m}$ high saddle between two conspicuously higher areas (Qirilali and Uluidenimanu) on a peninsula just south of modern Denimanu Village (Fig. 4A). The saddle settlement appears to have been divided into a secure residential section, characterized by yavu associated with several defensive stone walls, and a food preparation section (occupied today with food gardens) littered with shells and potsherds; the shell midden was $1.8 \mathrm{~m}$ deep in places (Fig. 4B). On the eastern side of the saddle, the steep protrusion named Qirilali (meaning "sound the slit-drum" as a warning) stands $20 \mathrm{~m}$ above the average saddle level and is extremely difficult to access. Some shell and potsherds are scattered around the summit, which is fringed with the remains of a stone wall. Qirilali is 


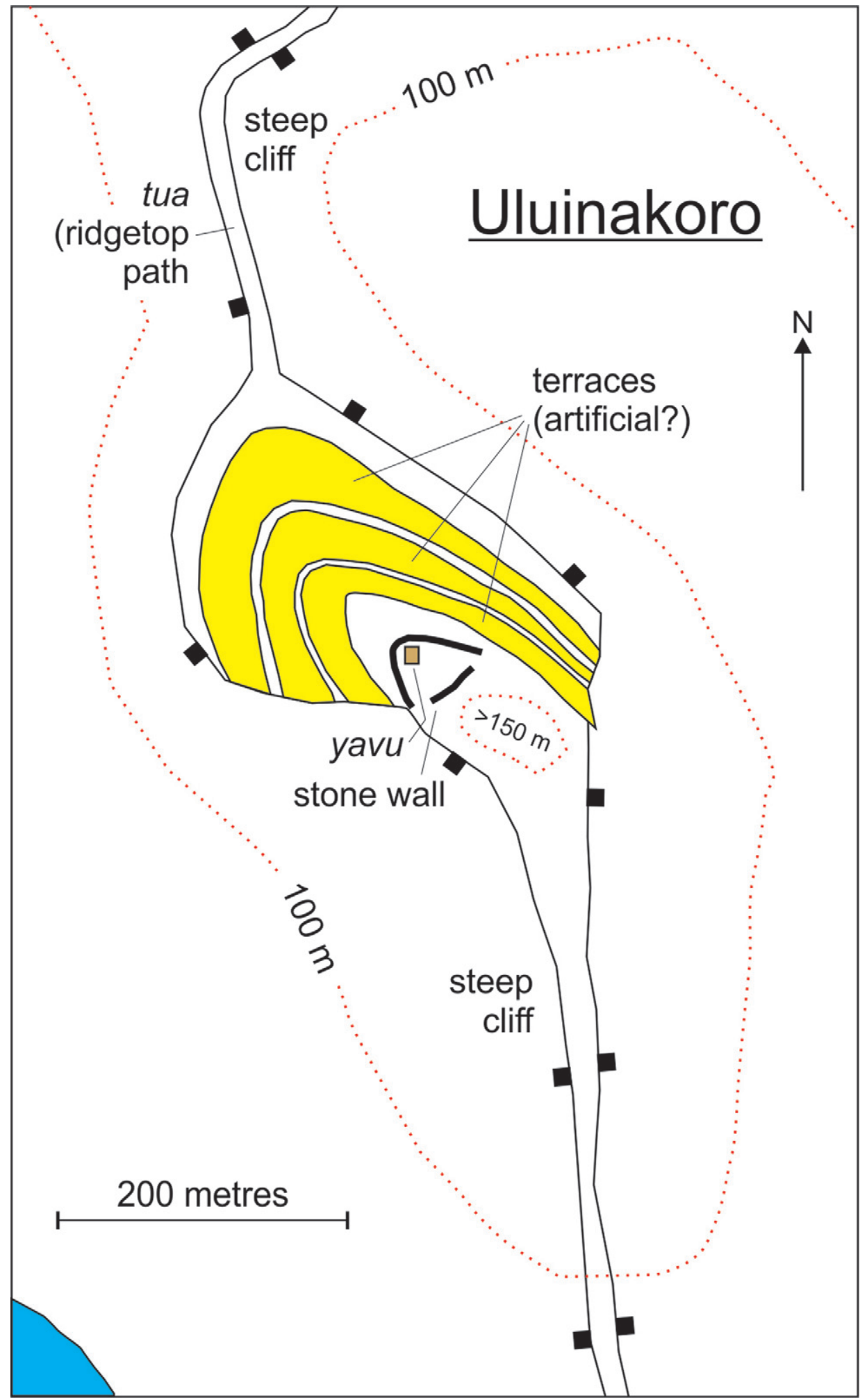

Fig. 2. Sketch map of Uluinakoro hillfort showing features described in text. 


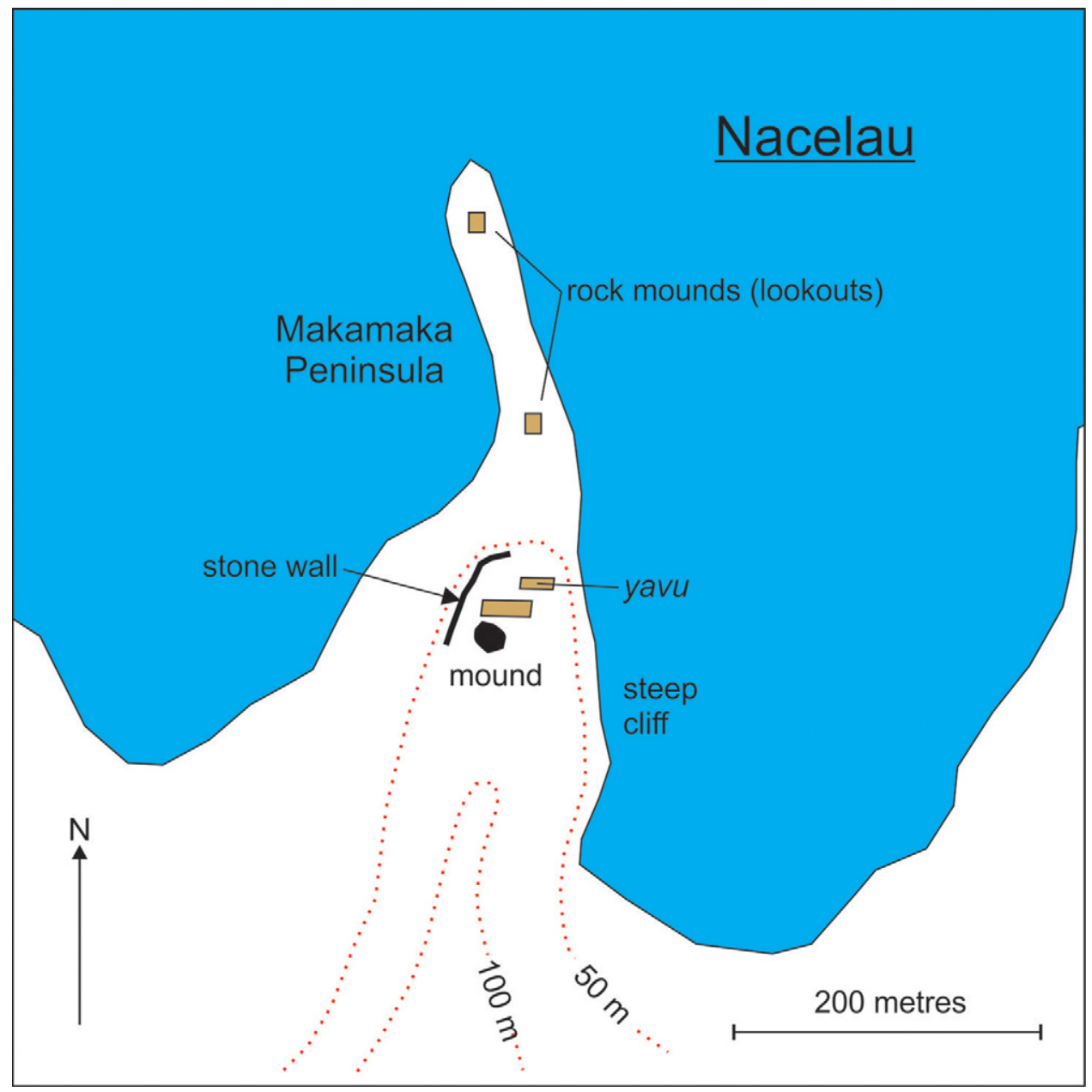

Fig. 3. Sketch map of Nacelau hillfort showing features described in text.

interpreted as a lookout point as well as an occasional place of refuge for the people who lived on the saddle below. To the west of the saddle lies the higher (summit elevation of $80 \mathrm{~m}$ amsl) yet more readily accessible hill of Uluidenimanu. Despite the presence of stone walls in and around its highest parts, an absence of visible potsherds or shellfish remains on Uluidenimanu suggests its principal function was as a lookout post rather than a place of occupation. It seems likely that the entire site was functionally connected to others higher up on Yadua during the hillfort period, being principally a place where shellfish could be gathered and processed and perhaps a place where less elite people lived and watched for approaching enemies. Oral traditions are consistent with this interpretation, insisting that there was no conflict within Yadua at any time in the past, only danger from outsiders coming across the sea. Such external sources of danger necessitated effective lookout sites on low cloud-free coastal promontories.

Uluikota is situated on the Naivoco Peninsula in northwest Yadua. It is a typical ridgetop site, reaching $110 \mathrm{~m}$ amsl, the visible remains of which are today dominated 

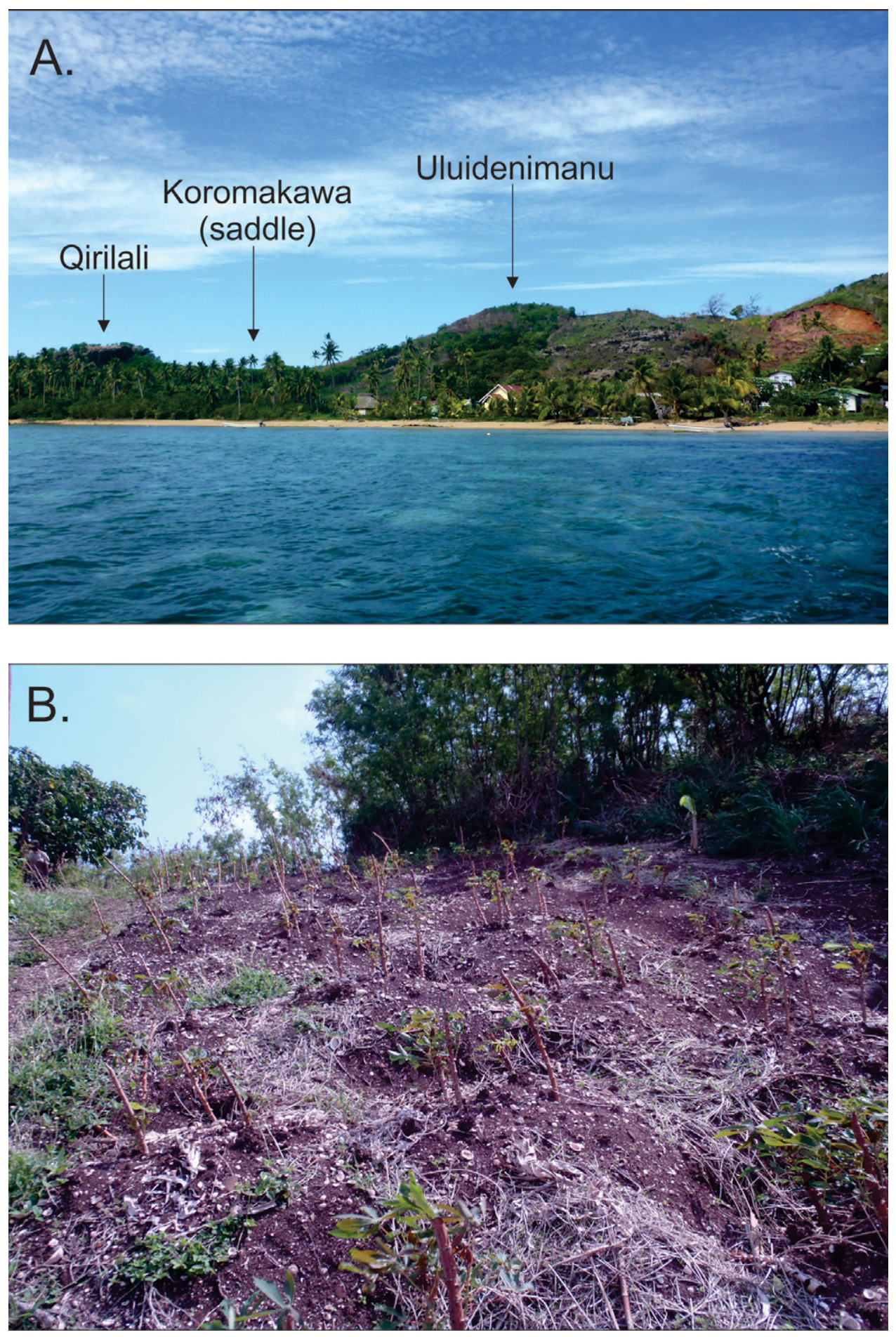

Fig. 4. Photographs of former upland Koromakawa settlement: (A) components of the settlement from east to west, including Qirilali, Koromakawa (occupying saddle ridge), Uluidenimanu (houses in modern Denimanu Village visible in middle ground) (photo by Piérick Martin); (B) surface shell and potsherd scatter at Koromakawa (photo by Patrick Nunn). 
by a wide circular stone wall $(2.5 \mathrm{~m}$ wide by $80 \mathrm{~cm}$ high) that describes a circle around $30 \mathrm{~m}$ in diameter. Oral traditions recall Uluikota as a "place of prayer," a sacred site which the people of Yadua have deliberately not cultivated for generations and rarely visit. It seems likely that this was a multi-purpose site. It was well positioned as a lookout and a first line of defense for sites higher up, but later became a site with spiritual associations that now appear to be lost. It is likely that the function of Uluikota was connected with the people of the former villages of Cukuvou and Talai nearby. Oral traditions suggested that Yadua Island's settlements were never inhabited all at the same time. Instead, people would move from one village to the next depending on food availability and threats from outside tribes. Yet each hillfort is situated almost directly above a former coastal settlement: Koromakawa above Denimanu, Talai above Cukuvou, and Uluinakoro above Vagairiki.

\section{Dating}

Four shellfish samples were submitted for radiocarbon age determination (Table 1). Owing to the existence of a radiocarbon plateau around the time to which they were dated, these samples date from anywhere between A.D. 1680 and 1950 (radiocarbon zero). However, given that "pottery production ceased approximately 200 years ago in the area" (Sepeti Matararaba, pers. comm. 2018) and that potsherds were recovered from as deep as $1.70 \mathrm{~m}$ in midden, it is likely that the actual ages are closer to the older end of the determined range, so perhaps A.D. 1680-1750 (270-200 cal. B.P.). This conclusion implies that Yadua Island's hillforts are similar in age to other recorded hillforts in Fiji (Nunn 2012; Robb and Nunn 2014b).

This conclusion is also consistent with the range of decorative styles and techniques observed on the potsherds recovered from upland sites on Yadua which likely belong to the Vuda Phase of Fiji ceramic history that began about A.D. 1100-1400 and lasted until perhaps A.D. 1800 (Burley and Clark 2003; Clark and Anderson 2009; Green 1963; Hunt and Cochrane 2018; Nakoro pers. comm. 3 July 2018).

Table i. Radiocarbon Dates from Yadua TP1

\begin{tabular}{|c|c|c|c|c|c|c|}
\hline SITE & LAB. NO. & SAMPLE MATERIAL & $\begin{array}{l}\text { DEPTH } \\
(\mathrm{CM})\end{array}$ & $\delta^{13} \mathrm{C}$ & $\begin{array}{l}\text { CONVENTIONAL } \\
{ }^{14} \text { C AGE (B.P.) }\end{array}$ & $\begin{array}{l}\text { CAL. }{ }^{14} \text { C AGE A.D./B.C. } \\
\text { AT } 95.4 \% \text { PROBABILITY }\end{array}$ \\
\hline $\begin{array}{r}\text { Koromakawa } \\
\text { (Yadua-A) }\end{array}$ & Wk-46548 & Gafrarium pectinatum & $160-170$ & $0.9 \pm 0.3 \%$ & $488 \pm 49$ & A.D. $1715-1950$ \\
\hline $\begin{array}{r}\text { Koromakawa } \\
\text { (Yadua-B) }\end{array}$ & Wk-46549 & Anadara antiquata & $160-170$ & $1.3 \pm 0.3 \%$ & $544 \pm 43$ & A.D. $1680-1950$ \\
\hline $\begin{array}{r}\text { Koromakawa } \\
\text { (Yadua-C) }\end{array}$ & Wk-46550 & Anadara antiquata & $110-120$ & $0.7 \pm 0.3 \%$ & $487 \pm 41$ & A.D. $1720-1950$ \\
\hline $\begin{array}{l}\text { Uluinakoro } \\
\text { (Yadua-D) }\end{array}$ & Wk-46551 & Anadara antiquata & $20-30$ & $-0.8 \pm 0.3 \%$ & $489 \pm 77$ & A.D. $1692-1950$ \\
\hline
\end{tabular}

Note: All dates from University of Waikato Radiocarbon Dating Laboratory, corrected using marine correction factor $(\Delta R)$ of $11 \pm 26$ years (Petchey et al. 2008) and calibrated using IntCal09 and Marine09 curves in OxCal v4.1.7 (Reimer et al. 2013). 


\section{DISCUSSION}

Radiocarbon ages and pottery decoration point towards an occupation of the hillforts on Yadua during the later seventeenth century, a time when those on the adjoining mainland (Vanua Levu) were probably also occupied. It is possible that this age is not that of hillfort establishment; the best-preserved midden at Koromakawa is likely to have been created perhaps only late in the hillfort period when outside threats had waned and occupation just $40 \mathrm{~m}$ amsl was considered safe. If this inference is correct, then it may be that hillforts were established first on Yadua a few hundred years earlier, as they were on the north coast of nearby Viti Levu Island and in the Sigatoka Valley (Kumar et al. 2006; Nunn 2012). It would indeed be surprising if the story of Yadua was significantly different from that of other Fiji islands.

However compelling this scenario, it should not be forgotten that many hilltop fortifications on Yadua are not well preserved, which limits interpretation. Local informants admitted that many stone walls on some peaks had been dismantled, their constituent rocks moved elsewhere or discarded if they interfered with cropping or posed hazards to grazing animals.

Cross-ridge ditches may once have existed on several peaks, including the approaches to Uluidenimanu. These artificial landforms were common defensive structures and often contained sharpened stakes on which attackers might be impaled; these ditches have been recorded at other hillforts in Fiji (Clunie 1977; Field 1998; Robb and Nunn 2014b).

In addition to insisting that there was never intertribal conflict between Yadua people, several informants from Denimanu explained that hillforts were not all occupied simultaneously, rather that people moved from one to another as proximal resources became exhausted. Such information underscores the complexities that undoubtedly prevailed during the perhaps 400-year duration of the hillfort period on Yadua and in similar contexts elsewhere.

Unsurprisingly, the oral traditions collected from people in modern Yadua are more informative and convincing when more recent times are discussed (Cashman and Cronin 2008; Jones et al. 2007; Mercer 2008). Some informants alluded to the pairing between hillforts and coastal settlements: how the people of Uluinakoro settled Vagairiki, while those from Talai settled nearby Cukuvou and those from Koromakawa established modern Denimanu (Fig. 1). There seems little reason to doubt that these pairs represent at least a threefold division of Yadua people which carried forward into the mid-nineteenth century contact and colonial period when traditional Fijian society was upended and eventually reconfigured (France 1969).

\section{CONCLUSION}

There is some evidence that people living on Yadua Island during the last millennium were subject to climate-driven environmental stress that led to a prolonged food crisis and thence to conflict. The conflict necessitated abandonment of coastal settlements in favor of upland settlements that were fortified to improve their natural defensive attributes. Anyone walking along the ridges leading to Uluinakoro will encounter the remains of tens of thousands of edible shells on the ground surface, leaving no doubt that people lived on this peak (and similar others on Yadua) in large numbers for a long time. Potsherd analysis and radiometric ages suggest that such areas were occupied around A.D. 1700, but they were perhaps first established around A.D. 1400-1500, 
making them coeval with hillforts elsewhere in Fiji and other tropical Pacific Island groups (Field and Lape 2010; Nunn 2007b).

Key questions remain that could be answered by more intensive fieldwork and recording of oral traditions on Yadua and similar islands. One question that has not been satisfactorily answered concerns the continuity of hillfort occupation, in other words whether people lived for generations permanently on mountaintops or whether their occupation of these fortified sites was punctuated by periods of lowland/coastal occupation when conflict subsided. Only in a few places has the archaeological and oral-historical record proved sufficiently fine-grained to hint at an answer to this question (Anderson and Kennett 2012; Best 1984).

Another set of questions has to do with the food strategies of hillfort dwellers on islands like Yadua. There is evidence from larger islands in Fiji (and elsewhere in the tropical Pacific) that hillfort dwellers routinely went downslope to collect shellfish from nearby coastal and riverine environments and then bring them back up to hillforts for consumption by residents, a roundtrip journey of perhaps 11-13 hours (Field 2003; Robb and Nunn 2014a; Robb and Nunn 2014b). Yet the existence of agricultural terraces around many former hillforts has also been demonstrated in Fiji and elsewhere in the high-island groups of the tropical Pacific (Kuhlken 1999, 2002). This suggests that taro and yams were essential ingredients of hillfort dwellers' subsistence. As an anonymous British official in Fiji in the 1860s informatively observed:

[The] jealousy that made every village distrustful of its neighbours, compelled the inhabitants to fortify themselves on the most inaccessible heights, and prevented them from cultivating any land beyond the few feet around each man's dwelling; if more were required, the cultivator, afraid to descend into the plain discovered some spot in the recesses of the mountains where he might plant his yams secure from molestation. (COC 1864)

This research has shown that new information about last-millennium settlement in the Pacific Islands can still be obtained from fieldwork on islands like Yadua, supplemented by oral traditions, although owing to the increasing reach of globalization these are likely to disappear within a few decades (Janif et al. 2016). Together with the ongoing physical degradation of human-made structures in the uppermost parts of islands like Yadua, the situation appears such that research of the kind described in this article is becoming a greater priority for the future.

\section{ACKNOWLEDGMENTS}

The authors are grateful to the people of Denimanu, on Yadua Island, for their hospitality and their cooperation with this research. We are especially thankful to Denimanu's headman, Atami Ravulo, for his assistance with fieldwork over a two-week period on Yadua in September 2017 and to our other consultants from Denimanu, especially Master Seci Loaloa, Jeremaia Ratabua, and Jotame Ratabua. We are grateful to Sepeti Matararaba and Elia Nakoro of the Fiji Museum for their insights. Wendy Taylor and Roselyn Kumar helped alert us to the existence of extant stories about hillforts on Yadua Island. The University of the Sunshine Coast is acknowledged for its help in funding this research.

\section{REFERENCES CITED}

Anderson, Atholl J., And Douglas J. Kennett, eds.

2012 Taking the High Ground: The Archaeology of Rapa, a Fortified Island in Remote East Polynesia. Canberra: Australian National University E-Press. 
Anderson, Atholl J., Douglas J. Kennett, and Eric Conte

2012 The prehistory of Rapa Island, in Taking the High Ground: The Archaeology of Rapa, a Fortified Island in Remote East Polynesia: 247-256, ed. A. J. Anderson and D. J. Kennett. Canberra: Australian National University E-Press.

Best, Simon Barrington

1984 Lakeba: The Prehistory of a Fijian island. Ph.D. thesis. University of Auckland.

Büntgen, Ulf, Vladimir S. Myglan, Frederik Charpentier Ljungqvist, Michael McCormick, Nicola Di Cosmo, Michael Sigl, Johann Jungclaus, Sebastian Wagner, Paul J. Krusic, Jan Esper, Jed O. Kaplan, Michiel A. C. De Vaan, Jurg Luterbacher, Lukas Wacker, Willy Tegel, and Alexander V. Kirdyanov

2016 Cooling and societal change during the Late Antique Little Ice Age from 536 to around 660 A.D. Nature Geoscience 9(3):231-236.

Burley, David V., and JefFrey Clark

2003 The archaeology of Fiji/western Polynesia in the post-Lapita era, in Pacific Archaeology: Assessments and Prospects, Proceedings of the International Conference for the 50th Anniversary of the First Lapita Excavation, Kone-Noumea 2002: 221-235, ed. Christophe Sand. Noumea: Services des Musees et du Patrimoine.

Burley, David V., Travis Freeland, and Jone Balenaivalu

2015 Nineteenth-century conflict and the Koivuanabuli fortification complex on Mali Island, northern Fiji. Journal of Island and Coastal Archaeology 11:107-121.

CANNON, TERry

2015 Disasters, climate change and the significance of 'culture', in Cultures and Disasters: Understanding Cultural Framings in Disaster Risk Reduction: 88-106, ed. F. Krüger, G. Bankoff, T. Cannon, B. Orlowski, and E.L.F. Schipper. London: Routledge.

Cashman, Katharine V., and Shane J. Cronin

2008 Welcoming a monster to the world: Myths, oral tradition, and modern societal response to volcanic disasters. Journal of Volcanology and Geothermal Research 176:407-418.

Chew, Sing, and Daniel Sarabia

2016 Nature-culture relations: Early globalization, climate changes, and system crisis. Sustainability 8(1):68-96.

Clark, Geoffrey, and Atholl Anderson

2009 TA31: The Early Prehistory of Fiji. Terra Australis 31. Canberra: ANU E Press.

Clunie, F.G.A.

1977 Fijian Weapons and Warfare. Suva: Fiji Museum.

COC [Consular Outward Correspondence]

1864 [Unsigned letter] in Consular Outward Correspondence [folder], preserved at National Archives of Fiji, Suva.

Di Piazza, Anne, and Erik Pearthree

2001 An island for gardens, an island for birds and voyaging: A settlement pattern for Kiritimati and Tabuaeran, two mystery islands in the northern Lines, Republic of Kiribati. Journal of the Polynesian Society 110(2):149-170.

Dickinson, William R., and J. Stephen Athens

2007 Holocene paleoshoreline and paleoenvironmental history of Palau: Implications for human settlement. Journal of Island and Coastal Archaeology 2:175-196.

Field, Julie S.

1998 Natural and constructed defenses in Fijian fortifications. Asian Perspectives 37:32-58.

2003 The Evolution of Competition and Cooperation in Fijian Prehistory: Archaeological Research in the Sigatoka Valley, Fiji. Ph.D. diss. University of Hawai'i.

2004 Environmental and climatic considerations: A hypothesis for conflict and the emergence of social complexity in Fijian prehistory. Journal of Anthropological Archaeology 23: 79-99.

2008 Explaining fortifications in Indo-Pacific prehistory. Archaeology in Oceania 43:1-10.

Field, Julie S., and Peter V. Lape

2010 Paleoclimates and the emergence of fortifications in the tropical Pacific islands. Journal of Anthropological Archaeology 29:113-124. 
FitzPatrick, Scott M.

2010 A critique of the 'A.D. 1300 Event', with particular reference to Palau. Journal of Pacific Archaeology 1:168-173.

2011 Defending the defensible or offending the sensible? A response to Nunn and HunterAnderson. Journal of Pacific Archaeology 2:100-105.

Fitzpatrick, Scott M., and Atholl Anderson

2008 Islands of Isolation: Archaeology and the power of aquatic perimeters. Journal of Island and Coastal Archaeology 3:4-16.

Fitzpatrick, Scott M., Victor D. Thompson, Aaron S. Poteate, Matthew F. Napolitano, and Jon M. ERLANDSON

2016 Marginalization of the margins: The importance of smaller islands in human prehistory. Journal of Island and Coastal Archaeology 11:155-170.

France, Peter

1969 The Charter of the Land: Custom and Colonization in Fiji. Melbourne: Oxford University Press.

Giovas, Christina M.

2016 Though she be but little: Resource resilience, Amerindian foraging, and long-term adaptive strategies in the Grenadines, West Indies. Journal of Island and Coastal Archaeology 11:238-263.

Green, R. C.

1963 A suggested revision of the Fijian sequence. Journal of the Polynesian Society 72(3):235-253.

Guppy, H. B.

1903 Observations of a Naturalist in the Pacific between 1896 and 1899. London: Macmillan.

Harris, Matthew, and Marshall Weisler

2017 Two millennia of mollusc foraging on Ebon Atoll, Marshall Islands: Sustained marine resource use on a Pacific atoll. Archaeology in Oceania 53(1):41-57.

Hunt, Terry L., and Ethan E. Cochrane

2018 The Oxford Handbook of Prehistoric Oceania. Oxford University Press. DOI: 10.1093/oxfordhb/ 9780199925070.013.001.

Janif, Shaiza Z., Patrick D. Nunn, Paul Geraghty, William Aalbersberg, Frank R. Thomas, and Mereoni Camailakeba

2016 Value of traditional oral narratives in building climate-change resilience: Insights from rural communities in Fiji. Ecology and Society 21(2):7.

Jones, Sharyn, David W. Steadman, and Patrick M. O’day

2007 Archaeological investigations on the small islands of Aiwa Levu and Aiwa Lailai, Lau Group, Fiji. Journal of Island and Coastal Archaeology 2:72-98.

Keegan, William F., Scott M. Fitzpatrick, Kathleen Sullivan Sealey, Michelle J. Lefebvre, and Peter T. Sinelli

2008 The role of small islands in marine subsistence strategies: Case studies from the Caribbean. Human Ecology 36:635-654.

Kennett, Douglas, Atholl Anderson, Matthew Prebble, Eric Conte, and John Southon

2006 Prehistoric human impacts on Rapa, French Polynesia. Antiquity 80:340-354.

Kirch, P. V., A. S. Hartshorn, O. A. Chadwick, P. M. Vitousek, D. R. Sherrod, J. Coil, L. Holm, AND W. D. SHARP

2004 Environment, agriculture, and settlement patterns in a marginal Polynesian landscape. Proceedings of the National Academy of Sciences of the United States of America 101:9936-9941.

Kouwenberg, Lenny, Rike Wagner, Wolfram Kürschner, and Henk Visscher

2005 Atmospheric $\mathrm{CO}_{2}$ fluctuations during the last millennium reconstructed by stomatal frequency analysis of Tsuga heterophylla needles. Geology 33:33-36.

KuHLKen, Robert

1999 Warfare and intensive agriculture in Fiji, in The Prehistory of Food: Appetites for Change: 264-281, ed. C. Gosden and J. Hather. London: Routledge.

2002 Intensive agricultural landscapes of Oceania. Journal of Cultural Geography 19:161-195.

Kumar, Roselyn, Patrick D. Nunn, Julie S. Field, and Antoine De Biran

2006 Human responses to climate change around AD 1300: A case study of the Sigatoka Valley, Viti Levu Island, Fiji. Quaternary International 151:133-143. 
Lape, Peter V., and Chao Chin-Yung

2008 Fortification as a human response to late Holocene climate change in East Timor. Archaeology in Oceania 43:11-21.

Liu, Fenggui, and Zhaodong Feng

2012 A dramatic climatic transition at $\sim 4000 \mathrm{cal}$. yr BP and its cultural responses in Chinese cultural domains. The Holocene 22:1181-1197.

MERCER, P. M.

2008 Oral tradition in the pacific. Journal of Pacific History 14:130-153.

Nunn, Patrick D.

$2007 a$ The A.D. 1300 Event in the Pacific Basin. Geographical Review 97:1-23.

2007 b Climate, Environment and Society in the Pacific during the Last Millennium. Amsterdam: Elsevier.

2012 Na koronivalu ni Bā: Upland settlement during the last millennium in the Bā River Valley and Vatia Peninsula, northern Viti Levu Island, Fiji. Asian Perspectives 51:1-21.

Nunn, P. D., And Mike T. Carson

$2015 a$ Collapses of island societies from environmental forcing: Does history hold lessons for the future? Global Environment 8:109-131.

2015 bea-level fall implicated in profound societal change about $2570 \mathrm{cal}$ yr BP (620 BC) in western Pacific island groups. Geo: Geography and Environment 2:17-32.

Nunn, Patrick D., and Rosalind Hunter-Anderson

2011 Defending the defensible: A rebuttal of Scott Fitzpatrick's (2010) critique of the A.D. 1300 Event model with particular reference to Palau. Journal of Pacific Archaeology 2:92-99.

Nunn, Patrick D., Rosalind Hunter-Anderson, Mike T. Carson, Frank Thomas, Sean Ulm, and Michael J. Rowland

2007 Times of plenty, times of less: Last-millennium societal disruption in the pacific basin. Human Ecology 35:385-401.

Nunn, Patrick D., S. Matararaba, T. Ishimura, Roselyn Kumar, and Elia Nakoro

2005 Reconstructing the Lapita-era geography of northern Fiji: A newly-discovered Lapita site on Yadua Island and its implications. New Zealand Journal of Archaeology 26:41-55.

Nunn, Patrick D., and Fiona Petchey

2013 Bayesian re-evaluation of Lapita settlement in Fiji: Radiocarbon analysis of the Lapita occupation at Bourewa and nearby sites on the Rove Peninsula, Viti Levu Island. Journal of Pacific Archaeology 4:21-34.

O’Connor, Sue, Andrew McWilliam, Jack N. Fenner, and Sally Brockwell,

2012 Examining the origin of fortifications in East Timor: Social and environmental factors. Journal of Island and Coastal Archaeology 7:200-218.

PALmer, J. Bruce

1966 Archaeology in Fiji. Asian Perspectives 9(1):167-169.

1969 Fortified sites on ridge-junctions, Fiji. New Zealand Archaeological Association Newsletter 12:15-19.

PeARl, Frederic B.

2004 The chronology of mountain settlements on Tutuila, American Samoa. Journal of the Polynesian Society 113:331-348.

Perry, Charles A., and Kenneth J. Hsu

2000 Geophysical, archaeological, and historical evidence support a solar-output model for climate change. Proceedings of the National Academy of Sciences of the United States of America 97: 12433-12438.

Petchey, Fiona, Atholl Anderson, Alan Hogg, and Albert Zondervan

2008 The marine reservoir effect in the Southern Ocean: An evaluation of extant and new ?R values and their application to archaeological chronologies. Journal of the Royal Society of New Zealand 38:243-262. 
Reimer, Paula J., Edouard Bard, Alex Bayliss, J. Warren Beck, Paul G. Blackwell, Christopher B. Ramsey, Caitlin E. Buck, Hai Cheng, R. Lawrence Edwards, Michael Friedrich, Pieter M. Grootes, Thomas P. Guilderson, Haflidi Haflidason, Irka Hajdas, Christine Hatté, Timothy J. Heaton, Dirk L. Hoffmann, Alan G. Hogg, Konrad A. Hughen, K. Felix Kaiser, Brend Kromer, Sturt W. Manning, Mu Niu, Ron W. Reimer, David A. Richards, E. Marian Scott, John R. Southon, Richard A. Staff, Christian S. M. Turney, and Johannes Van Der Plicht

2013 IntCal13 and Marine13 radiocarbon age calibration curves 0-50,000 years cal B.P. Radiocarbon 55:1869-1887.

Rick, Torben C., Patrick V. Kirch, Jon M. Erlandson, and Scott M. Fitzpatrick

2013 Archeology, deep history, and the human transformation of island ecosystems. Anthropocene $4: 33-45$.

Robb, Kasey F., and Patrick D. Nunn

2012 Nature and chronology of prehistoric settlement on the Vatia Peninsula, northern Viti Levu Island, Fiji. Journal of Island and Coastal Archaeology 7:272-281.

2014a Changing role of nearshore-marine foods in the subsistence economy of inland upland communities during the last millennium in the tropical Pacific Islands: Insights from the Bā River Valley, northern Viti Levu Island, Fiji. Environmental Archaeology: Journal of Human Palaeoecology 19:1-11.

$2014 b$ Vatutāqiri: An immense stone-walled fortification on the Vatia Peninsula, northern Viti Levu Island, Fiji. People and Culture in Oceania 30:1-19.

Weber, S., T. Crowley, and G. van der Schrier

2004 Solar irradiance forcing of centennial climate variability during the Holocene. Climate Dynamics 22:539-553.

WEISLER, M. I.

1996 Taking the mystery out of the Polynesian "mystery" islands: A case study from Mangareva and the Pitcairn Group, in Oceanic Culture History: Essays in Honour of Roger Green: 615-629, ed. J. M. Davidson, G. Irwin, B. F. Leach, A. Pawley, and D. Brown. Auckland: New Zealand Journal of Archaeology Special Publication.

Wilkes, Charles

1845 Narrative of the United States Exploring Expedition during the Years 1838, 1839, 1840, 1841, 1842. Philadelphia: Lea and Blanchard. 